\title{
CELLULOLYTIC ACTIVITY OF ANTAGONIST MOULD CHAETOMIUM COCHLIODES, BIO-AGENT OF MICROBIAL PREPARATION KHETOMIK
}

\author{
A. S. Yovenko \\ Institute of Agricultural Microbiology and Agroindustrial Manufacture, NAAS, \\ City of Chernihiv
}

\begin{abstract}
Cellulolytic activity of antagonist mould Chaetomium cochliodes 3250 has been investigated. It was shown that C. cochliodes 3250 synthesizes complex of cellulases degradation enzymes of cell wall. The highest parameters of endo, exoglucosidase and $\beta$ glucosidase activity of mould are shown at Day 9 of cultivation. High cellulase activity causes the ability of mould to penetrate plant tissues. C. cochliodes 3250, which was introduced in the root zone of buckwheat seeds, forms fruiting bodies on the surface of root fibrils and penetrates cells of rhizodermis.
\end{abstract}

Key words: C. cochliodes 3250, cellulase, endoglucanase, exoglucanase, $\beta$ glucosidase, plant-microbial associations, mycorrhiza.

Formation of close symbiotic associations between microorganisms and plants is a complex ecological process [1]. Mycorrhiza-forming fungi take a special place among many rhizospheric organisms. By some estimates, about 250 thous. of plant species, including cultural, are able to form mycorrhiza formation. Characteristic features of such plant-microbial interactions are the formation of specific structures or penetration of fungus into the plant tissues, or both simultaneously. Availability of mycorrhiza is a normal condition for most plants under any conditions and is mutually beneficial and interconnected partnership, formed between plant roots and fungi [2]. Mechanism of mycorrhizal symbiosis formation and functional integration of symbionts continues to attract attention of many researchers.

It is known that some micromycetes are able to penetrate plants by hydrolysis of cellular wall. Infectious hyphae, at early stages of symbiosis synthesise enzymes of cellular wall degradation (pectinase, endopoligalacturonaze, cellulase), which are required for penetration of fungi in the root [1]. With the penetration of arbuscularvesicular fungi in the cellular wall of plants, no direct participation of such enzymes like cellulase and xyloglucanase was seen, however, it is known that the activity of these hydrolytic enzymes increases in roots with mycorrhiza [3; 4]. Species of the genus Rhizoctonia, similar to the Orchid symbionts, form a cellulases and pectinases that can accompany colonization of plant tissues [5]. There are published data regarding ability to decompose pectin, cellulose, and hemicellulose (the main structural components of plant cell walls) and oxidize phenolic compounds, by the fungus Rhizoscyphusericae, microsymbiont of ericoid mycorrhiza [6]. It is known that most symbionts of ectomycorrhiza have limited ability to use lignin and cellulose as substrate for plants, significantly weaker than in wood-destroying fungi [7]. However, the ability to decompose cellulose and pectin may be associated with fungus penetration into the root tissues, where formation of enzymes is localised and causes softening of cellular walls upon formation of Hartig mesh [8]. Several species of ectomycorrhiza fungi require association with plant root system for formation of fruit bodies [2].

In recent years, it has been shown that saprotrophic soil fungi are also able to 
penetrate roots and cause positive changes in plants. Fungi of genus Trichoderma, Fusarium, Acremonium, Penicillium are able to infect plants and form endophytic associations with roots [9-11].

There are works that indicate the ability of the genus Chaetomium to show endophytic properties to certain plants. $C$. globosum penetrates tissues of tropical cereal and legume grasses [12; 13]. Previously, it was shown that $C$. cochliodes 3250 forms endophytic associations with plants of spring wheat and soybean [14; 15].

The aim of our work was to investigate activity of cellulolytic complex of the fungus $C$. cochliodes 3250 and its ability to penetrate root tissue of beech buckwheat.

Materials and methods. Natural strain of the cup fungus $C$. cochliodes Palliser 3250, deposited in the All-Union Scientific Research Institute of Agricultural Microbiology (now - State Scientific Institution of All-Russian Scientific Research Institute of Agricultural Microbiology of the Russian Academy of Sciences) was used as a study object.

Preliminary check of the ability of $C$. cochliodes 3250 to synthesize cellulases was conducted by qualitative (plate) method. Studied fungus was cultivated on the Petri dishes during 10 days on the Czapek medium containing carboxymethylcellulose sodium salt (Na-CMC, $0.5 \%$ ) [16] and cellobiase (0.2\%) [17] as a source of carbon and substrate for enzymes. Congo red ( $0.5 \%$, injected into the agar medium) was used as an indicator cellulase complex. Cellulose activity was assessed by the ratio of enlightenment zones diameter $\left(\mathrm{d}_{\text {zones }}\right)$ to diameter of colonies ( $\left.\mathrm{d}_{\text {colonies }}\right)$.

During the second stage, the overall cellulosolytic activity of $C$. cochliodes 3250 by the active of cellulase complex components was measured. For this purpose, fungi were superficially cultivated during 28 and 12 days, respectively, on a modified synthetic Czapek medium (g/L: $\left(\mathrm{NH}_{4}\right)_{2} \mathrm{HPO}_{4}$ - 2.5; $\mathrm{K}_{2} \mathrm{HPO}_{4}-1.0 ; \mathrm{MgSO}_{4}-0.5 ; \mathrm{KCl}-$ $0.5 ; \mathrm{FeSO}_{4}-0.01$ ). As the only source of carbon, strip of filter paper $(50 \mathrm{mg})$ was used. $\mathrm{pH}-7.0$.
Sowing was carried out by spore suspension $\left(\mathrm{T}=1 * 10^{6} \mathrm{CFU}\right)$ in the amount of $5 \%$ from the volume of digest medium. Seed material C. cochliodes 3250 was obtained by flushing of conidia and fragments of fungal from slope wort agar. Titre was determined in Horiaiev chamber. Superficial cultivation was performed in the test tubes with $5 \mathrm{~mL}$ of digest medium at $26{ }^{\circ} \mathrm{C}$.

Measurement of total cellulosolytic activity was performed at day 7, 14, 21, 28 of cultivation. With further measurement of the activity of cellulosolytic complex components, registration was performed at day 3, 6, 9 and 12 of cultivation. Czapek digest medium without fungus inoculum was used as a control. After the cultivation, biomass was eliminated by filtration through a porcelain sieve, filtrate of culture liquid was used for tests.

The study was conducted in 3-time biological and 3-time analytical replications.

Such amount of enzyme that forms $1 \mathrm{mg}$ of reducing sugars during $60 \mathrm{~min}$ was taken as the unit of total cellulase activity. Enzymes of cellulase complex include exoglucanases (such amount of enzyme that forms $1 \mathrm{mg}$ of reducing sugars during $60 \mathrm{~min}$ was taken as the unit of exoglucanase activity), endoglucanase and $\beta$-glucosidase (such amount of enzyme that forms $1 \mathrm{mg}$ of reducing sugars during $30 \mathrm{~min}$ was taken as the unit of endoglucanase and $\beta$-glucosidase activity). As a substrate, $50 \mathrm{mg}$ of avicel (microcrystalline cellulose), $1 \mathrm{~mL}$ of $0.5 \%$ $\mathrm{Na}-\mathrm{CMC}$ solution and $1 \mathrm{~mL}$ of $0.025 \%$ cellobiose in $0.05 \mathrm{M}$ sodium citrate buffer respectively was used. Amount of reducing sugars was measured by Somogyi-Nelson method [18], at the same time investigated mixture was incubated at $40^{\circ} \mathrm{C}$. Calibration curve was plotted by standard glucose solutions.

The ability of $C$. cochliodes 3250 to form associations with plants of beech buckwheat of variety Antaria was tested in a vegetation experiment. Plants were grown in a sterile substrate (vermiculite) for 30 days. Plastic $2.0 \mathrm{~L}$ vessel of 10.5 x $15.5 \mathrm{~cm}$ were used. Seeds of beech buckwheat Antaria was 
sown at a depth of $2.0 \mathrm{~cm}, 25$ plants was grown in each vessel with further thinning to 20. Pre-test processing of seeds with biopreparation Khetomik, 1 gram of which contains $1.8 * 10^{9}$ ascospores of $C$. cochliodes 3250, at the rate of 40 thousand CFU per 1 seed was performed. Replication of the experiment is three-time.

Staining of cuts on plant roots was performed by Kobel method [18]. Temporary microsections were examined under the microscope MC 200(T) (Micros, Austria), took images using digital colour camera DSC-S650 Sony.

Calculations and statistical processing of the results was performed by conventional methods. Parametric criteria of normal distribution, calculating arithmetic mean and mean square deviation at the significance level less than 0.05 were used. The analysis was performed using Microsoft Excel software.

Therefore, saprophytic fungus $C$. cochliodes 3250 is able to synthesize enzymes of cellulase complex (exoglucanases, endoglucanases, $\beta$ glucosidases) that can provide its penetration into the plant roots. It is shown that $C$. cochliodes 3250 forms fruit bodies on the surface of root hairs and penetrates rhizodermis cells. 